\title{
THE APPRAISAL OF SELF-CARE AGENCY SCALE AND ITS RELATION TO HEALTH BEHAVIORS AND CONDITIONS IN OLDER ADULTS
}

\author{
Christian Díaz de León Castañeda1,2, Ana Celia Anguiano Morán, \\ Magdalena Lozano Zúñigaํy y Emma Flores Mendoza' \\ ${ }^{1}$ Michoacan University of Saint Nicholas of Hidalgo; ${ }^{2}$ National Council for \\ Science and Technology (Mexico)
}

\begin{abstract}
The objective of this work was to contribute to the study of the validity of the "Appraisal of Self-care Agency Scale" (ASA scale) in older adults and to analyze its association with health-related behaviors and conditions. A questionnaire was constructed and applied to 165 elderly residents of Michoacán, Mexico. A confirmatory factor analysis of the scale's one-dimensional model was carried out, and also an analysis of internal consistency, as well as an analysis of the relationship with other variables based on group comparisons, exploring the effect of the elimination of inverse items. Overall, the reduced scale performed better although the one-dimensional model maintained a limited fit in the confirmatory factor analysis. Internal consistency was satisfactory in both scales ( $\alpha$ coefficient $=.806$ and .826 , respectively). In addition, some important group comparisons were identified with anthropometric measurements. In conclusion, tests were found supporting the validity of the ASA scale in older adults, although more evidence is still needed regarding its construct and criterion validity.

KEYWORDS: self-care, health promotion, behaviors, healthy lifestyle, health status, aged.
\end{abstract}

\section{Resumen}

Este trabajo tuvo por objetivo contribuir en el estudio de la validez de la "Escala de valoración de la capacidad de autocuidado" (escala ASA) en adultos mayores y analizar su asociación con conductas y condiciones relacionadas con la salud. Se construyó un cuestionario y se aplicó a 165 adultos mayores residentes de Michoacán (México). Se realizó un análisis factorial confirmatorio del modelo unidimensional de la escala, así como un análisis de consistencia interna, así como un análisis de relación con otras variables basado en comparaciones de grupos, explorando el efecto de la eliminación de ítems inversos. La escala reducida tuvo mejor desempeño en general, aunque el modelo unidimensional mantuvo un ajuste limitado en el análisis factorial confirmatorio. La consistencia interna fue satisfactoria en ambas escalas (Coeficiente $\alpha=0,806$ y 0,826 , respectivamente), además se identificaron algunas comparaciones de grupo importantes con

Correspondence: Ana Celia Anguiano Morán, Faculty of Nursing, Michoacan University of Saint Nicholas of Hidalgo, Ventura Puente No. 115, Centro, 58000 Morelia, Michoacán (Mexico). E-mail: ana.anguiano@umich.mx 
mediciones antropométricas. En conclusión, se encontraron pruebas que apoyan la validez de la escala ASA en adultos mayores, aunque continúa pendiente generar más evidencia en cuanto a su validez de constructo y criterio.

PALABRAS CLAVE: autocuidado, promoción de la salud, conducta, estilo de vida saludable, estado de salud, adulto mayor.

\section{Introduction}

In Mexico, the health of the elderly is a very important issue for health policies and systems, since this population can be considered vulnerable in various aspects. Regarding health, this population is more vulnerable both to communicable diseases (CD) and chronic non-communicable diseases (NCDs). This becomes important in the context of the demographic and epidemiological transition that the country is experiencing, which leads to high economic implications for individuals, their families, health systems and society (Gómez-Dantés et al., 2016; Kuri-Morales, 2011; Lozano et al., 2014; Omran, 1971).

According to the socio-ecological model, in the adoption of healthy behaviors, several contextual factors may come into play at higher levels than the individual and the immediate social environment, such as those related to the educational system, the health system and the political, economic and social structure (Bronfenbrenner, 1977; McCormack, Thomas, Lewis and Rudd, 2017). This can be particularly important in countries like Mexico, which has a fragmented health system that implies the existence of a mosaic of health service delivery systems, depending of the persons' employment status and payment capacity. Briefly, the public system is subdivided into two large sectors: that aimed at the population with formal employment through social Security schemes, being the most important the Instituto Mexicano del Seguro Social [Mexican Social Security Institute] (IMSS); and that aimed at the population without formal employment, mainly in charge of of the Secretaría de Salud [Ministry of Health] (SSA) through the Instituto de Salud para el Bienestar [Institute of Health for Well-being] (INSABI) and the Servicios Estatales de Salud [State Health Services] (SESA), although there are other schemes such as the IMSS-Bienestar program (González-Block et al, 2020).

Based on the results of the Encuesta Nacional de Salud y Nutrición [National Health and Nutrition Survey] (ENSANUT) (National Institute of Public Health [INSP], 2020), it has been identified that great challenges persist in older adults in terms of nutritional and health conditions. In particular, the high prevalence of NCDs such as diabetes, hypertension and dyslipidemias in this age group stands out. Likewise, great challenges have been identified in terms of the quality of the health system's response to these health problems, reflected through various indicators of aspects such as carrying out preventive actions, timely medical diagnosis, patients' self-care, and the control of these health conditions; that also present significant inequalities and inequities associated with sociodemographic, socioeconomic and cultural factors (Campos, Hernández, Pedroza, Medina, \& 
Barquera, 2018; Flores-Hernández et al., 2015; Rojas et al., 2018; Salinas, Manrique, de la Cruz, \& Rivera, 2019; Villalobos et al., 2019).

With this background, the importance of promoting the involvement or commitment of older adults in taking care of their own health has been emphasized, that is, their capacity for self-care regarding the adoption of healthy behaviors and habits based on evidence to maintain or improve their health conditions (Barello, Graffigna, \& Savarese, 2014; Battersby et al., 2010; Weinger, Beverly, \& Smaldone, 2014). These actions could also allow better results in terms of costs from different perspectives (for the patient, the health system, or society).

There are several conceptual and instrumental approaches to self-care from different disciplines (Richard \& Shea, 2011; Van De Velde et al., 2019; Wilkinson \& Whitehead, 2009). One of the most notable theoretical developments is the selfcare deficit theory, which is framed in general nursing theory and defines the term "self-care agency" as the ability of people to participate in their own care (Orem, 2001). This theory has allowed the development of various instrumental approaches in various countries around the world (Matarese, Lommi, \& De Marinis, 2017; Muñoz, Cabrero, Richart, Orts, \& Cabañero, 2005).

One of these approaches is the "Appraisal of Self-care Agency Scale" (ASA Scale), initially developed in English and Dutch and proposed as a 24-item scale for generic use. Later it has been adapted to other languages including Spanish (Evers, Isenberg, Philipsen, Senten, \& Brouns, 1993). However, it has not been possible to clearly define the underlying dimensions, which is why it has been recommended to consider them as one-dimensional. Some works have contributed in this field, such as the definition of a shorter version of 15 items in three dimensions (Sousa et al., 2010) which, although its validity has been analyzed in other countries and languages (Alhambra-Borrás, Durá-Ferrandis, Garcés-Ferrer, \& Sánchez-García, 2017; Guo et al., 2017), the content validity could be compromised in addition to keeping inverse items, which are not currently recommended (Vigil-Colet, NavarroGonzález, \& Morales-Vives, 2020). Furthermore, there is limited validity evidence based on the relationship with other variables.

The first Spanish version was developed and studied in Mexico (Gallegos, 1998) and later, this version was adapted in Colombia, keeping three inverse items (Manrique \& Velandia, 2009; Velandia \& Rivera, 2009). This version has also been studied in other Latin American countries such as Chile and Costa Rica (Espinoza et al., 2020; Leiva, Cubillo, Porras, Ramírez, \& Sirias, 2016a, 2016b). However, like the versions in other languages, the dimensions of the scale have not been clearly identified, in addition, they have limited evidence of validity based on other variables relationships.

The objective of this work is to study the psychometric properties of the onedimensional model of the Spanish version of the ASA Scale, as well as to analyze its relationship with other variables (behaviors and health-related conditions) in Mexican older adults, exploring the performance of a short version based on the elimination of inverse items. 


\section{Method}

\section{Participants}

The questionnaire was applied to 165 older adults. Table 1 shows the sociodemographic characteristics, health-related behaviors (protective and risky) and health conditions of the people interviewed. In the sample, the majority were women and the predominant age category was 60-70 years. Regarding affiliation to health institutions, the majority were affiliated with the services of the Secretaria de Salud de Michoacán (SSM). Regarding health-related behaviors, about half stated that they never exercised. In addition, some participants were identified who reported consuming alcoholic beverages and smoking. Regarding the health conditions related to metabolic diseases, taking the body mass index (BMI) as an indicator, the vast majority of the participants were in pre-obesity and obesity conditions. Furthermore, in terms of risk levels identified based on waist circumference, a high proportion of the participants were identified as being at high risk. Important proportions of the sample declared having NCDs (hypertension and diabetes).

Table 1

Characteristics of the participants $(N=165)$

\begin{tabular}{|l|c|c|}
\hline \multicolumn{1}{|c|}{ Variable } & $n$ & $\%$ \\
\hline Socio-demographic characteristics & & \\
\hline Sex & & \\
\hline Female & 114 & 69.1 \\
\hline Male & 51 & 30.9 \\
\hline Age & & \\
\hline $60-65$ & 58 & 35.2 \\
\hline $66-70$ & 47 & 28.5 \\
\hline $71-75$ & 28 & 17.0 \\
\hline $76-80$ & 17 & 10.3 \\
\hline$>80$ & 15 & 9.1 \\
\hline Level of educational attainment & & \\
\hline No basic education & 39 & 24.2 \\
\hline Primary & 64 & 39.8 \\
\hline Secondary & 18 & 11.2 \\
\hline High school or technical degree & 17 & 10.6 \\
\hline Bachelor's degree & 23 & 14.3 \\
\hline Civil status & & \\
\hline Single & 72 & 44.2 \\
\hline With a partner & 91 & 55.8 \\
\hline Health service affiliation ${ }^{\text {a }}$ & & \\
\hline Ministry of Health of Michoacán (SSM) & 94 & 61.8 \\
\hline Mexican Social Security Institute (IMSS) & 40 & 26.3 \\
\hline Institute of Security and Social Services for State Workers (ISSSTE) & 17 & 11.2 \\
\hline Other & 1 & 0.7 \\
\hline
\end{tabular}




\begin{tabular}{|c|c|c|}
\hline Variable & $n$ & $\%$ \\
\hline \multicolumn{3}{|l|}{ Health behaviors } \\
\hline \multicolumn{3}{|l|}{ Frequency of physical exercise } \\
\hline Never & 70 & 49.6 \\
\hline Once a week & 10 & 7.1 \\
\hline Two or three times a week & 27 & 19.1 \\
\hline Daily & 34 & 24.1 \\
\hline \multicolumn{3}{|l|}{ Alcohol consumption } \\
\hline Yes & 30 & 18.2 \\
\hline No & 135 & 81.8 \\
\hline \multicolumn{3}{|l|}{ Smoke } \\
\hline Yes & 18 & 10.9 \\
\hline No & 147 & 89.1 \\
\hline \multicolumn{3}{|l|}{ Health conditions } \\
\hline \multicolumn{3}{|l|}{ Body Mass Index (BMI) ${ }^{b}$} \\
\hline Low weight $(\leq 18,49)$ & 3 & 2.0 \\
\hline Normal $(18,50-24,99)$ & 28 & 18.8 \\
\hline Pre-obesity $(25,00-29,99)$ & 63 & 42.3 \\
\hline Obesity $(>30,00)$ & 55 & 36.9 \\
\hline \multicolumn{3}{|l|}{ Waist circumference } \\
\hline$<80 \mathrm{~cm}$ & 14 & 8.5 \\
\hline $81-85 \mathrm{~cm}$ & 9 & 5.5 \\
\hline $86-90 \mathrm{~cm}$ & 19 & 11.5 \\
\hline $91-95 \mathrm{~cm}$ & 34 & 20.6 \\
\hline $96-100 \mathrm{~cm}$ & 31 & 18.8 \\
\hline$>100 \mathrm{~cm}$ & 44 & 26.7 \\
\hline \multicolumn{3}{|l|}{ Hypertension } \\
\hline Yes & 81 & 50.3 \\
\hline No & 80 & 49.7 \\
\hline \multicolumn{3}{|l|}{ Diabetes } \\
\hline Yes & 49 & 31.2 \\
\hline No & 108 & 68.8 \\
\hline \multicolumn{3}{|c|}{ Self-perception of physical health status } \\
\hline Bad & 20 & 12.5 \\
\hline Regular & 78 & 48.8 \\
\hline Good & 62 & 38.8 \\
\hline \multicolumn{3}{|l|}{ Self-perception of mental health status } \\
\hline Bad & 10 & 6.2 \\
\hline Regular & 57 & 35.2 \\
\hline Good & 95 & 58.6 \\
\hline \multicolumn{3}{|l|}{ Depression } \\
\hline Yes & 44 & 29.7 \\
\hline No & 104 & 70.3 \\
\hline
\end{tabular}

Notes: The SSM is one of the State Health Services (SESA) and provides health care to the State of Michoacán population without formal employment); the IMSS and ISSSTE are social security schemes aimed at provide health services for people with formal employment. BMl $\mathrm{Kg} / \mathrm{m}^{2}$ 
Instruments

a) Appraisal of Self-care Agency Scale (ASA) (Evers et al., 1993). A slight modification of the Spanish version adapted in Colombia was used (Manrique \& Velandia, 2009). This version is made up of 24 items that evaluate the frequency in which self-care activities are carried out at four levels: $1=$ never, 2 = almost never, $3=$ always, and $4=$ almost always; it is worth mentioning that three items have an inverse sense (items 6, 11 and 20) and the score on this scale has a minimum of 24 and a maximum of 96.

b) Ad hoc questionnaire for the exploration of behaviors and health conditions of the elderly. This questionnaire included ten items to gather information regarding the following: 1) healthy behaviors, specifically the frequency with which older adults performed physical exercise at four response levels ( $1=$ never, $2=$ once a week, $3=$ two or three times a week, and $4=$ daily); 2) risk behaviors, specifically, the consumption of alcohol and tobacco was asked at two response levels ( $1=$ Yes, $2=$ No); 3 ) health conditions, it was asked about previous diagnoses of NCDs (diabetes, hypertension) and mental illnesses (depression); and 4) the perception of the respondents regarding their state of physical and mental health in three response levels ( $1=$ Bad, $2=$ Regular, and $3=$ Good).

c) To measure body weight, an analog scale (Taurus, Obeliz, capacity 130 $\mathrm{kg}$ ) was used.

d) To measure height, a wall stadiometer (SECA 206, capacity $220 \mathrm{~cm}$ ) was used.

e) To measure the waist circumference, an anthropometric tape with millimeter precision (SECA 201) was used.

\section{Procedure}

An observational cross-sectional study was carried out. The study population was older adults residing in Morelia, Michoacán, Mexico and assigned to the Group of Older Adults (GAM) organized by the Secretaría de Salud de Michoacán [Ministry of Health of Michoacán] (SSM) to participate in recreational and health promotion activities. A sample of participants was obtained by convenience. Using this approach, an event was organized for the GAM. This event was held in November 2015 and took place at the Urban Health Center "Dr. Juan Manuel González Ureña", which is a primary-care services center of the SSM.

The questionnaire was given to the participants in printed form to be filled out by them in a private place. Help was provided to participants upon request. After solving the questionnaire, their waist circumference, body weight, and height were taken using the aforementioned instruments.

From weight and height measurements, the body mass index (BMI) was calculated. With this information, comparison groups were obtained considering the following obesity categories based on BMI $\left(\mathrm{Kg} / \mathrm{m}^{2}\right)$ : low weight $(\leq 18.49)$, 
normal (18.50-24.99), pre-obesity (25.0-29.99), and obesity (>30.00). Besides, six groups of waist circumference were obtained.

Prior to fieldwork, the research protocol was approved by the Ethics Committee of the Facultad de Enfermería, Universidad Michoacana de San Nicolás de Hidalgo (Approval number: CIB / FacEnf / 036/2015).

\section{Data analysis}

The distribution of the scale items was analyzed through descriptive statistics of mean and standard deviation, as well as shape indicators such as skewness and kurtosis.

It was performed a confirmatory factor analysis (CFA), through which the one-dimensional model of the ASA scale was tested using the weighted least square mean and variance (WLSMV) as estimation method, which considers the ordinal nature of the items. As for fit indices of the one-dimensional model, the chi-square statistic $\left(\chi^{2}\right.$, fit criterion $\left.p>.05\right)$; the comparative fit index (CFl; acceptable fit criterion $>.95$ ); the standardized root mean square residual (SRMR; acceptable fit criterion <.05 and optimal <.08); and the root mean square error of approximation (RMSEA; acceptable fit criterion < .07) were obtained. As an approach to assessing the reliability of the ASA scale, internal consistency was analyzed by Cronbach's alpha.

Descriptive statistics were made of the scores obtained with the original ASA scale (24 items) as well as a reduced version (21 items) based on the elimination of inverse items. The Kolmogorov-Smirnov and Shapiro-Wilk statistical tests were performed to test the normality of the distribution of the global score of both scales in the sample (IBM, 2018; Sprent \& Smeeton, 2001).

The analysis of the relationship of the ASA scale with other variables was carried out mainly through comparison of groups. Statistical significance analysis of the comparison of groups was performed through non-parametric statistical tests (Sprent \& Smeeton, 2001). For this latter, in the comparison of self-care capacity in two groups, the median test (MT) and the Mann-Whitney $U$ test (UMW) were used. In more than two groups, the median test (MT) and the Kruskal Wallis test (KWT) were used for groups of nominal categories and the JonckheereTerpstra test (JTT) for groups of ordinal categories. Likewise, the relationship with other variables was analyzed through effect size calculations, using Cohen's $d$ for the comparison of two groups and the $\eta^{2}$ for the comparison of three or more groups (Dominguez-Lara, 2018).

For data analysis, the SPSS v. 25 for the management of the information collected, descriptive analysis, internal consistency, and comparison of groups. To perform the CFA analysis, the RStudio program was used, using the psych, semTools, lavaan, and semPlot packages. 


\section{Results}

\section{Self-care ability}

The descriptive results of the scores obtained for each item of the ASA scale are shown in Table 2.

Table 2

Descriptive statistics of the ASA Scale items in the participants

\begin{tabular}{|c|c|c|c|c|}
\hline Item & $M$ & $S D$ & Asymmetry & Kurtosis \\
\hline $\begin{array}{l}\text { 1. As circumstances change, I make adjustments to } \\
\text { maintain my health }\end{array}$ & 2.98 & 0.78 & -0.81 & 0.79 \\
\hline $\begin{array}{l}\text { 2. I check to see if the activities I normally do to stay } \\
\text { healthy are good }\end{array}$ & 3.04 & 0.67 & -0.89 & 2.00 \\
\hline $\begin{array}{l}\text { 3. If I have trouble moving or getting around, I } \\
\text { manage to get help }\end{array}$ & 2.41 & 1.07 & -0.09 & -1.30 \\
\hline $\begin{array}{l}\text { 4. I can do what is necessary to keep the } \\
\text { environment where I live clean }\end{array}$ & 3.14 & 0.43 & 0.33 & 4.45 \\
\hline 5. First, I do whatever it takes to stay healthy & 3.05 & 0.62 & -1.11 & 3.48 \\
\hline $\begin{array}{l}\text { 6. I think I lack the necessary strength to take care of } \\
\text { myself as I should* }\end{array}$ & 2.30 & 1.19 & 0.22 & -1.49 \\
\hline $\begin{array}{l}\text { 7. If I want, I can find ways to take care of my health } \\
\text { and improve the level of health I have now }\end{array}$ & 3.09 & 0.62 & -0.83 & 2.56 \\
\hline 8. I change how often I shower to stay clean & 2.90 & 0.78 & -0.84 & 0.82 \\
\hline $\begin{array}{l}\text { 9. I make changes to my food to maintain my } \\
\text { appropriate weight }\end{array}$ & 2.85 & 0.91 & -0.81 & -0.01 \\
\hline $\begin{array}{l}\text { 10. When there are situations that affect me, I handle } \\
\text { them so that they do not affect my way of being }\end{array}$ & 3.03 & 0.74 & -0.95 & 1.44 \\
\hline $\begin{array}{l}\text { 11. I think about exercising and getting some rest } \\
\text { during the day, but I don't have time to do it* }\end{array}$ & 2.68 & 1.03 & -0.46 & -0.92 \\
\hline 12. When I need help, I can turn to my old friends & 2.68 & 0.93 & -0.67 & -0.42 \\
\hline 13. I can get enough sleep in order not to feel tired & 2.89 & 0.85 & -0.76 & 0.25 \\
\hline $\begin{array}{l}\text { 14. When they give me guidance on my health, I ask } \\
\text { them to clarify what I do not understand }\end{array}$ & 2.96 & 0.71 & -1.18 & 2.28 \\
\hline 15. I examine my body to see if there is any change & 2.88 & 0.79 & -0.91 & 0.86 \\
\hline $\begin{array}{l}\text { 16. I have been able to change deeply ingrained } \\
\text { habits in order to improve my health }\end{array}$ & 2.90 & 0.78 & -0.91 & 0.94 \\
\hline $\begin{array}{l}\text { 17. When I need to take a new medicine, I turn to my } \\
\text { health professional for information about side } \\
\text { effects }\end{array}$ & 2.86 & 0.83 & -0.99 & 0.75 \\
\hline $\begin{array}{l}\text { 18. I am able to take steps to prevent my family and I } \\
\text { from being in danger. }\end{array}$ & 3.07 & 0.54 & -1.11 & 5.37 \\
\hline $\begin{array}{l}\text { 19. I am able to evaluate how well what I do helps } \\
\text { me to stay healthy }\end{array}$ & 2.95 & 0.62 & -1.35 & 3.71 \\
\hline $\begin{array}{l}\text { 20. Because of my daily activities, it is very difficult } \\
\text { that I have time to take care of myself* }\end{array}$ & 2.48 & 1.10 & -0.11 & -1.32 \\
\hline $\begin{array}{l}\text { 21. If my health is affected, I can get information to } \\
\text { know what to do ... }\end{array}$ & 3.02 & 0.69 & -1.13 & 2.49 \\
\hline
\end{tabular}




\begin{tabular}{|l|c|c|c|c|}
\hline \multicolumn{1}{|c|}{ Item } & $M$ & $S D$ & Asymmetry & Kurtosis \\
\hline 22. If I can't take care of myself, I seek help & 2.87 & 0.76 & -1.11 & 1.41 \\
\hline 23. I can set aside some time for myself & 2.95 & 0.65 & -1.32 & 3.29 \\
\hline $\begin{array}{c}\text { 24. Despite my limitations in moving, I am able to } \\
\text { take care of myself as I like }\end{array}$ & 2.98 & 0.65 & -1.17 & 2.95 \\
\hline
\end{tabular}

Note: *Items with inverse sense.

The results of the factor loads obtained in the CFA are shown in Table 3 . In the 24-item ASA scale, items 6, 8, 11, and 20 showed low factor loads $(<0.300)$. Considering the current recommendations, it was proposed to eliminate the items with inverse loads $(6,11$, and 20$)$ to remain as a reduced scale of 21 items, whose factorial loads were higher than the previously mentioned criterion (except for item 8).

\section{Table 3}

Standardized factor loads obtained with the CFA of the one-dimensional model for the original and reduced ASA scales

\begin{tabular}{|c|c|c|c|c|c|}
\hline Item & $\begin{array}{c}\text { ASA Scale - } \\
\text { original } \\
(24 \text { items })\end{array}$ & $\begin{array}{c}\text { ASA Scale - } \\
\text { reduced } \\
(21 \text { items })\end{array}$ & Item & $\begin{array}{c}\text { ASA Scale - } \\
\text { original } \\
(24 \text { items })\end{array}$ & $\begin{array}{c}\text { ASA Scale - } \\
\text { reduced } \\
(21 \text { items })\end{array}$ \\
\hline 1 & .605 & .603 & 13 & .331 & .337 \\
\hline 2 & .613 & .611 & 14 & .738 & .735 \\
\hline 3 & .404 & .397 & 15 & .607 & .609 \\
\hline 4 & .340 & .338 & 16 & .577 & .580 \\
\hline 5 & .464 & .471 & 17 & .650 & .656 \\
\hline 6 & .246 & - & 18 & .763 & .763 \\
\hline 7 & .375 & .370 & 19 & .626 & .633 \\
\hline 8 & .274 & .260 & 20 & .250 & - \\
\hline 9 & .518 & .520 & 21 & .581 & .577 \\
\hline 10 & .341 & .347 & 22 & .441 & .432 \\
\hline 11 & .188 & - & 23 & .580 & .586 \\
\hline 12 & .409 & .413 & 24 & .614 & .614 \\
\hline
\end{tabular}

Notes: $\mathrm{ASA}=$ Appraisal of Self-care Agency. Factor loads were obtained with the one-dimensional model of the original and reduced ASA (without releasing covariances between item errors). Results indicating low factor saturation $(<0.300)$ are shown in bold.

The results of the fit indices obtained for both scales in the CFA are shown in Table 4. Compared with the original ASA (24 items), the reduced ASA (21 items) presented better fit indices. In addition, the addition of two covariances between items errors allowed these indices to improve in both scales so that the best fit was obtained with the reduced ASA considering the covariance between item errors. The elimination of inverse items also allowed a slight improvement in Cronbach's alpha, for the original ASA scale it was .806, while for the reduced ASA scale it was .826. 
Table 4

Fit indices obtained in the CFA for the one-dimensional model of the original and reduced ASA scales

\begin{tabular}{|l|c|c|c|c|c|c|}
\hline \multicolumn{1}{|c|}{ Scale } & $\begin{array}{c}\text { Item error } \\
\text { covariances }\end{array}$ & $\chi^{2}$ & $d f$ & CFI & SRMR & RMSEA \\
\hline $\begin{array}{l}\text { ASA Scale -original } \\
\text { (24 items) }\end{array}$ & None & $472.61^{* * *}$ & 252 & 0.839 & 0.102 & 0.073 \\
\cline { 2 - 7 } $\begin{array}{l}\text { ASA Scale - reduced } \\
\text { (21 items) }\end{array}$ & e6-e20/ e14-e21 & $447.57^{* * *}$ & 250 & 0.856 & 0.098 & 0.069 \\
\cline { 2 - 7 } & None & $378.36^{* * *}$ & 189 & 0.858 & 0.099 & 0.078 \\
\hline
\end{tabular}

Notes: ASA = Appraisal of Self-care Agency. Only the two main covariances between item errors were considered. ${ }^{* * *} p<0.001$.

Regarding the descriptive statistics of the global scores obtained for both scales, for the 24-item ASA scale the following were obtained: $M=68.95, S D=$ 8.24, asymmetry $=-0.57$ and kurtosis= 2.48; while for the 20-item ASA scale the following were obtained: $M=61.48, S D=7.43$, Asymmetry= -0.57 and Kurtosis= 3.05. The values obtained for skewness and kurtosis seem to show that they have slightly left-loaded and leptokurtic distributions. The inferential normality tests carried out showed statistically significant values $(p<.001)$ for both scales and in both statistical tests (SW, KS), so it is inferred that the scale scores are not normally distributed in the population.

The results regarding the relationship analysis between the scores obtained with both ASA scales with health-related behaviors and conditions are shown in Table 5. The relationship pattern with other variables was similar in both scales. Regarding the relationship with health behaviors, no statistically significant comparison of groups was found ( $p>.05)$; however, for the descriptive comparison based on effect sizes, results were found that could be considered important, mainly in the comparisons of smoking and alcohol consumption groups $(d>0.100)$.

Regarding the relationship of the scores obtained with both ASA scales with health conditions, a statistically significant comparison of groups $(p<.05)$ was found with the waist circumference (JTT test). Furthermore, in the comparison by BMI categories, although it was not statistically significant ( $p>.05)$, in the descriptive comparison based on effect sizes a result was found that can be considered important $\left(\eta^{2}>0.040\right)$. 


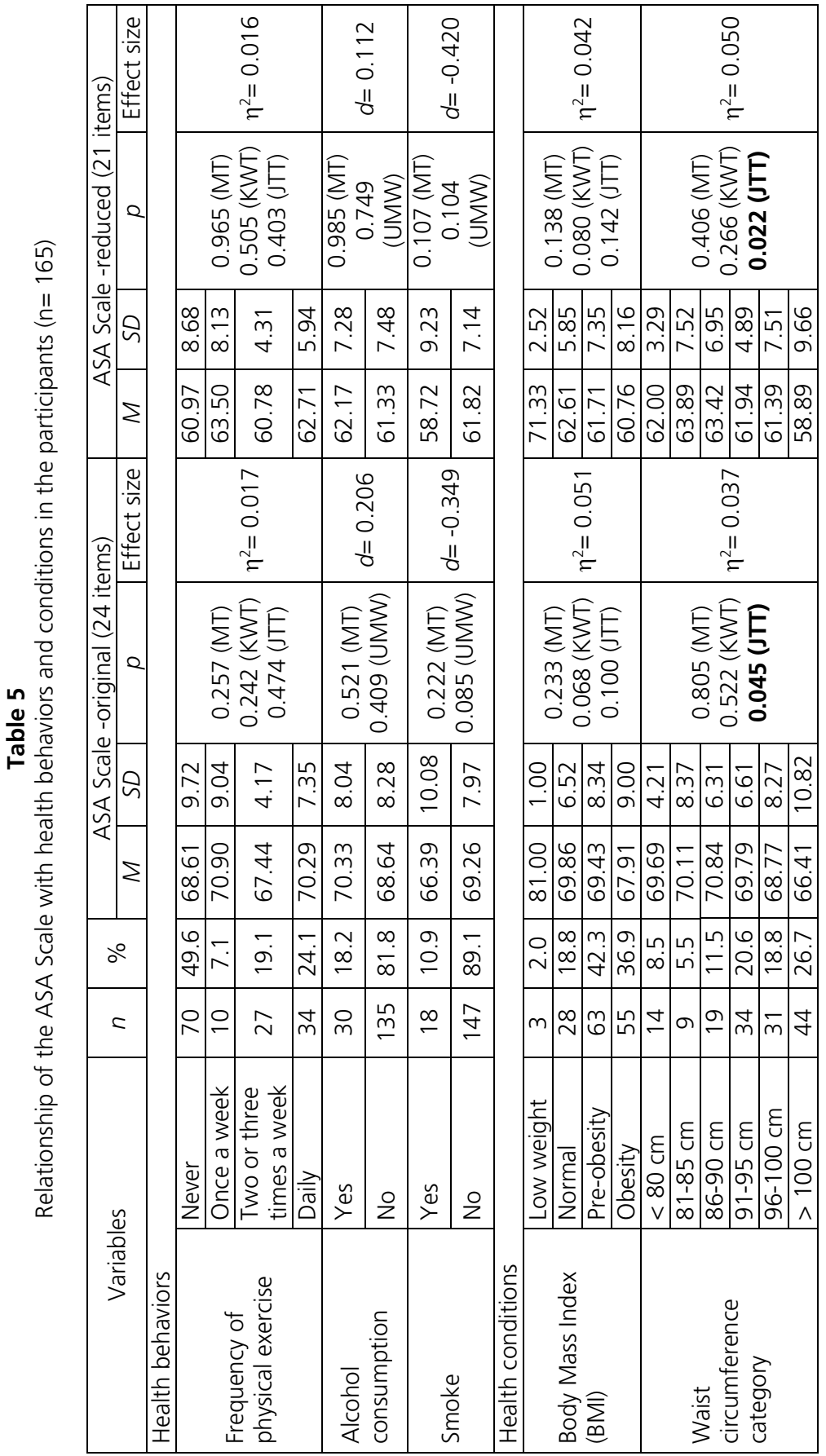




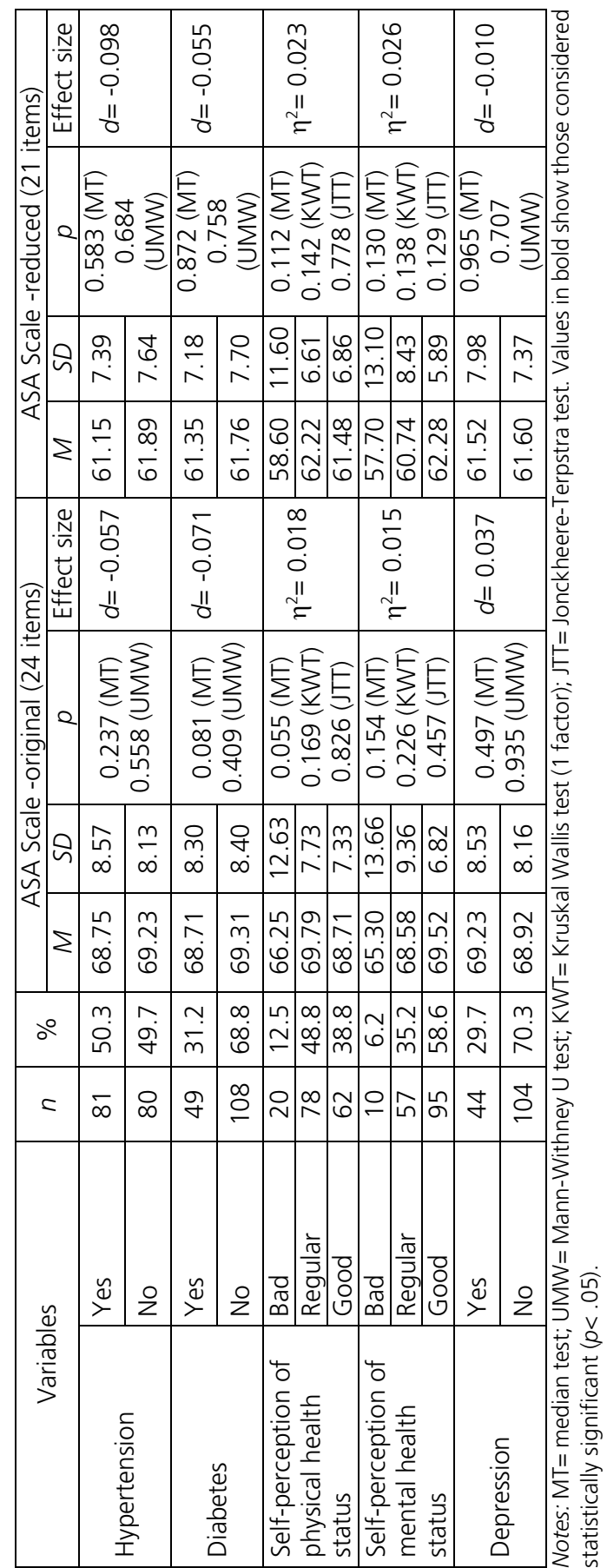




\section{Discussion}

This section presents some final reflections on the findings and the methodological approach of the study, identifying opportunities for future studies.

Regarding the CFA, it was not possible to meet the criteria of a good fit of the model. This could be because the ASA scale was considered as onedimensional, following the recommendations of the scale developers (Evers et al., 1993). It is worth mentioning that since its development, the ASA scale has shown a complex factorial structure that has prevented the characterization of the identified dimensions, except for some proposals that have generated shorter versions of the scale that could compromise the integrity of its content (Sousa et al., 2010).

In the case of the Spanish version of the ASA scale used in this study, as for the versions in other languages, the dimensions have not been clearly identified and it has been suggested to consider the scale as one-dimensional (Espinoza et al., 2020; Leiva et al., 2016a, 2016b; Manrique \& Velandia, 2009). In this study, through the CFA of the one-dimensional model, a factorial structure different from that observed in other age groups such as adolescents and older adults was found (Espinoza et al., 2020; Manrique \& Velandia, 2009). In addition to recommendations from the literature mentioned before (Vigil-Colet et al., 2020), the results of this study suggested the elimination of inverse items to have a reduced ASA scale of 21 items, which showed a better performance.

Regarding the evaluation of internal consistency, the global Coefficient $\alpha$ obtained with the 24-item ASA scale (0.806) was higher than that obtained in a study carried out in Colombia with older adults (0.689) (Manrique \& Velandia, 2009), but lower than the achieved in a study carried out in Costa Rica in adults (0.840) (Leiva et al., 2016b, 2016a) and the obtained in a study carried out in Chile in adolescents (0.880) (Espinoza et al., 2020). However, the reduced ASA scale of 21 items proposed in this study allowed to improve this coefficient (0.826).

Regarding the other variables relationship analysis based on comparison of groups, it was observed that the scores obtained with both scales behave in a similar way, which was reflected through descriptive indicators (effect sizes) and inferential statistical tests (non-parametric). It is important to say that the comparison of groups carried out can be considered as an analysis of discriminant validity (known groups) since it seeks to identify whether the scale scores change in these groups.

In the other variables relationship analysis carried out from an inferential approach, only one comparison of groups was statistically significant (waist circumference), while the descriptive approach based on the analysis of effect sizes managed to show several associations of the ASA scale with health behaviors and conditions, highlighting the analysis by BMl groups. The comparison of groups with the latter and waist circumference stand out because these health indicators (actually risk factors for NCDs) were evaluated in an objective and directly observable way, independently of the participants' responses and perceptions, where many factors can induce bias. 
As opportunities for further studies, the following are identified: 1) to explore in more detail the factorial structure of the ASA scale towards the development of a structure that preserves its properties in different demographic groups, or look at the possibility of developing more clearly defined scales for each group (particularly the older adults), that can better meet the adjustment criteria in the (FA; 2 ) in the study of other variables relationships, it is important to explore the criterion validity through the association or correlation with other scales or objective indicators of healthy or risky behaviors, as well as health conditions, including, in addition to the variables integrated in this study others that may be important in older adults, such as the feed quality, physical exercise quality, rest quality, etc; and 3) explore construct validity through the correlation with known scales of self-care-related constructs such as health literacy, self-efficacy, empowerment, and healthpromoting or risky behaviors attitudes scales.

This study contributes to generating evidence that supports the use of the ASA scale in older adults. However, it is important to generate more evidence in this field to generate tools that can be used in research, as well as clinical and public health practices.

\section{References}

Alhambra-Borrás, T., Durá-Ferrandis, E., Garcés-Ferrer, J., \& Sánchez-García, J. (2017). The Appraisal of Self-Care Agency Scale-Revised (ASA-R): Adaptation and validation in a sample of Spanish older adults. Spanish Journal of Psychology, 20, e48, 1-10. doi: $10.1017 /$ sjp.2017.52

Barello, S., Graffigna, G., \& Savarese, M. (2014). Engaging patients in health management: Towards a preliminary theoretical conceptualization. Psicologia della Salute, (3), 11-33. doi: 10.3280/PDS2014-003002

Battersby, M., Von Korff, M., Schaefer, J., Davis, C., Ludman, E., Greene, S. M., Parkerton, M., \& Wagner, E. H. (2010). Twelve evidence-based principles for implementing selfmanagement support in primary care. Joint Commission Journal on Quality and Patient Safety, 36(12), 561-570. doi: 10.1016/S1553-7250(10)36084-3

Bronfenbrenner, U. (1977). Toward an Experimental Ecology of Human Development. American Psychologyst, 513-531.

Campos, I., Hernández, L., Pedroza, A., Medina, C., \& Barquera, S. (2018). Hipertensión arterial en adultos mexicanos: Prevalencia, diagnóstico y tipo de tratamiento [Arterial hypertension in Mexican adults: Prevalence, diagnosis and type of treatment]. Ensanut MC 2016. Salud Pública de México, 60(3), 233. doi: 10.21149/8813

Dominguez-Lara, S. (2018). Magnitud del efecto, una guía rápida [Effect size, a quick guide]. Educación Médica, 19(4), 251-254. doi: 10.1016/j.edumed.2017.07.002

Espinoza, M., Huaiquián, J., Sanhueza, O., Luengo, L., Valderrama, M., \& Ortiz, N. (2020). Validation of the Appraisal of Self-care Agency Scale (ASA) in Chilean adolescents. Escola Anna Nery, 24(2), 1-7. doi: 10.1590/2177-9465-ean-2019-0172

Evers, G. C. M., Isenberg, M. A., Philipsen, H., Senten, M., \& Brouns, G. (1993). Validity testing of the Dutch translation of the Appraisal of the Self-Care Agency A.S.A. Scale. International Journal of Nursing Studies, 30(4), 331-342. doi: 10.1016/0020-7489 (93)90105-4

Flores-Hernández, S., Saturno-Hernández, P. J., Reyes-Morales, H., Barrientos-Gutiérrez, T., Villalpando, S., \& Hernández-Ávila, M. (2015). Quality of diabetes care: The challenges of an increasing epidemic in Mexico. Results from two National Health Surveys (2006 
and 2012). PLoS One, 10(7), 1-15. doi: 10.1371/journal.pone.0133958

Gallegos, C. E. (1998). Validez y confiabilidades de la versión en español de la escala: Valoración de las capacidades de autocuidado. Desarrollo Científico de Enfermería, 6(9), 260-266.

Gómez-Dantés, H., Fullman, N., Lamadrid-Figueroa, H., Cahuana-Hurtado, L., Darney, B., Avila-Burgos, L., Correa-Rotter, R., Rivera, J. A., Barquera, S., González-Pier, E., Aburto-Soto, T., de Castro, E. F. A., Barrientos-Gutiérrez, T., Basto-Abreu, A. C., Batis, C., Borges, G., Campos-Nonato, I., Campuzano-Rincón, J. C., Cantoral-Preciado, A., Contreras-Manzano, A. G., ... Lozano, R. (2016). Dissonant health transition in the states of Mexico, 1990-2013: a systematic analysis for the Global Burden of Disease Study 2013. The Lancet, 388(10058), 2386-2402. doi: 10.1016/S01406736(16)31773-1

González-Block, M.A., Reyes-Morales, H., Cahuana-Hurtado, L., Balandrán, A., Méndez, E., \& Allin, S. (2020). Mexico: health system review. Health Systems in Transition, 22(2), i222. Retrieved from: https://apps.who.int/iris/handle/10665/334334

Guo, L., Söderhamn, U., McCallum, J., Ding, X., Gao, H., Guo, Q., Liu, K., \& Liu, Y. (2017). Testing and comparing two self-care-related instruments among older Chinese adults. PloS One, 12(8), e0182792. doi: 10.1371/journal.pone.0182792

Instituto Nacional de Salud Pública. (2020). Encuesta Nacional de Salud y Nutrición [National Health and Nutrition Survey] (ENSANUT), web page. https://ensanut.insp.mx/

Kuri-Morales, P. A. (2011). La transición en salud y su impacto en la demanda de servicios [The health transition and its impact on the demand for services]. Gaceta Médica de México, 147, 451-454.

Leiva, V., Cubillo, K., Porras, Y., Ramírez, T., \& Sirias, I. (2016a). Validación de apariencia, contenido y consistencia interna de la Escala de apreciación de agencia de autocuidado (ASA) para Costa Rica, segunda versión en español para población conocida sana [Validation appearance, content and internal consistency of the Appraisal of Self-Care Agency Scale (ASA) to Costa Rica, for second Spanish version known population healthy]. Enfermería Actual en Costa Rica, 30, 1-20.

Leiva, V., Cubillo, K., Porras, Y., Ramírez, T., \& Sirias, I. (2016b). Validación de la Escala de apreciación de agencia de autocuidado (ASA) para Costa Rica, para población con enfermedad crónica [Validation of the Appraisal of Self-Care Agency Scale (ASA) for Costa Rica, for people with chronic diseases]. Enfermería Actual en Costa Rica, 31, 118. doi: 10.15517/revenf.v0i31.25486

Lozano, R., Gómez-Dantés, H., Pelcastre, B., Ruelas, M. G., Montañez, J. C., Campuzano, J. C., Franco, F., \& González, J. J. (2014). Carga de la enfermedad en México, 19902010. Nuevos resultados y desafíos [Burden of disease in Mexico, 1990-2010. New results and challenges]. Cuernavaca, México: Instituto Nacional de Salud Pública.

Manrique, F., \& Velandia, A. (2009). Análisis factorial de la Escala valoración de agencia de autocuidado (ASA) en Colombia [Factor analysis of the Appraisal of Self-Care Agency Scale (ASA) in Colombia]. Aquichan, 9(3), 222-235. doi: 10.5294/1521

Matarese, M., Lommi, M., \& De Marinis, M. G. (2017). Systematic review of measurement properties of self-reported instruments for evaluating self-care in adults. Journal of Advanced Nursing, 73(6), 1272-1287. doi: 10.1111/jan.13204

McCormack, L., Thomas, V., Lewis, M. A., \& Rudd, R. (2017). Improving low health literacy and patient engagement: A social ecological approach. Patient Education and Counseling, 100(1), 8-13. doi: 10.1016/j.pec.2016.07.007

Muñoz, C., Cabrero, J., Richart, M., Orts, M. I., \& Cabañero, M. J. (2005). La medición de los autocuidados: Una revisión de la bibliografía [Measurement of self-care: A literature review]. Enfermería Clínica, 15(2), 76-87. doi: 10.1016/\$11308621(05)71087-1 
Omran, A. (1971). The epidemiologic transition: A theory of the epidemiology of population change. The Milbank Memorial Fund Quarterly, 49(1), 509-538. doi: 10.1007/s13398014-0173-7.2

Orem, D. E. (2001). Nursing: concepts of practice (6 ${ }^{\text {th }}$ Ed.). St Louis, MO: Mosby.

Richard, A. A., \& Shea, K. (2011). Delineation of Self-Care and Associated Concepts. Journal of Nursing Scholarship, 43(3), 255-264. doi: 10.1111/j.1547-5069.2011.01404.x

Rojas, R., Basto, A., Aguilar, C., Zárate, E., Villalpando, S., \& Barrientos, T. (2018). Prevalencia de diabetes por diagnóstico médico previo en México [Prevalence of previously diagnosed diabetes mellitus in Mexico]. Salud Pública de México, 60(3), 224-232.

Salinas, A., Manrique, B., de la Cruz, V., \& Rivera, A. (2019). Socioeconomic inequalities in health and nutrition among older adults in Mexico. Salud Pública de México, 61(6)، 898-906. doi: 10.21149/10556

Sousa, V. D., Zauszniewski, J. A., Bergquist-Beringer, S., Musil, C. M., Neese, J. B., \& Jaber, A. F. (2010). Reliability, validity and factor structure of the Appraisal of Self-Care Agency Scale-Revised (ASAS-R). Journal of Evaluation in Clinical Practice, 16(6), 10311040. doi: 10.1111/j.1365-2753.2009.01242.x

Sprent, P., \& Smeeton, N. C. (2001). Applied nonparametric statistical methods (3rd Ed.). Boca Raton, FL: Chapman \& Hall/CRC.

Van De Velde, D., De Zutter, F., Satink, T., Costa, U., Janquart, S., Senn, D., \& De Vriendt, P. (2019). Delineating the concept of self-management in chronic conditions: A concept analysis. BMJ Open, 9(7). doi: 10.1136/bmjopen-2018-027775

Velandia, A., \& Rivera, L. N. (2009). Confiabilidad de la escala "Apreciación de la agencia de autocuidado" (ASA), segunda versión en español adaptada para población colombiana [Reliability of the "Appraisal of the Self-Care Agency" (ASA) scale, second version in Spanish adapted for the Colombian population]. Avances en Enfermería, 27(1), 38-47.

Vigil-Colet, A., Navarro-González, D., \& Morales-Vives, F. (2020). To reverse or to not reverse likert-type items: That is the question. Psicothema, 32(1), 108-114. doi: 10.7334/psicothema2019.286

Villalobos, A., Rojas-Martínez, R., Aguilar-Salinas, C. A., Romero-Martínez, M., MendozaAlvarado, L. R., Flores-Luna, M. L., Escamilla, A., \& Ávila-Burgos, L. (2019). Atención médica y acciones de autocuidado en personas que viven con diabetes, según nivel socioeconómico [Medical care and self-care actions in people living with diabetes, according to socioeconomic level]. Salud Pública de México, 61(6), 876. doi: 10.21149/10546

Weinger, K., Beverly, E. A., \& Smaldone, A. (2014). Diabetes self-care and the older adult. Western Journal of Nursing Research, 36(9), 1272-1298. doi: $10.1177 / 0193945914521696$

Wilkinson, A., \& Whitehead, L. (2009). Evolution of the concept of self-care and implications for nurses: A literature review. International Journal of Nursing Studies, 46(8), 1143-1147. doi: 10.1016/j.ijnurstu.2008.12.011 